This is an electronic reprint of the original article. This reprint may differ from the original in pagination and typographic detail.

\author{
Author(s): Reudler Talsma, Johanna Hendrika; Lindstedt, Carita; Pakkanen, Hannu; Lehtinen, \\ Inkeri; Mappes, Johanna
}

Title: $\quad$ Costs and benefits of plant allelochemicals in herbivore diet in a multi enemy world

Year: $\quad 2015$

Version:

Please cite the original version:

Reudler Talsma, J. H., Lindstedt, C., Pakkanen, H., Lehtinen, I., \& Mappes, J. (2015). Costs and benefits of plant allelochemicals in herbivore diet in a multi enemy world. Oecologia, 179(4), 1147-1158. https://doi.org/10.1007/s00442-015-3425-0

All material supplied via JYX is protected by copyright and other intellectual property rights, and duplication or sale of all or part of any of the repository collections is not permitted, except that material may be duplicated by you for your research use or educational purposes in electronic or print form. You must obtain permission for any other use. Electronic or print copies may not be offered, whether for sale or otherwise to anyone who is not an authorised user. 


\section{Costs and benefits of plant allelochemicals in herbivore diet in a}

2 multi enemy world

3

4 J. H. Reudler ${ }^{* a}$, C. Lindstedt ${ }^{\mathrm{a}}$, H. Pakkanen ${ }^{\mathrm{b}}$, I. Lehtinen ${ }^{\mathrm{ac}}$ and J. Mappes ${ }^{\mathrm{a}}$

$5{ }^{a}$ University of Jyvaskyla, Centre of Excellence in Biological Interactions, Department of Biology

6 and Environmental Science, P.O. Box 35, FI-40014 University of Jyvaskyla, Finland.

7 buniversity of Jyvaskyla, Department of Chemistry, P.O. Box 35, FI-40014 University of

8 Jyvaskyla, Finland.

$9 \quad{ }^{c}$ Department of Environmental Sciences, University of Helsinki, Helsinki, Finland.

$10 \quad$ *Corresponding author: jhtalsma@hotmail.com

\footnotetext{
${ }^{1}$ Author Contributions: JHR originally formulated the idea, JHR, CL and JM developed methodology, JHR and IL conducted field and lab work, HP developed methods for chemical analyses, JHR performed statistical analyses JHR, $\mathrm{CL}$ and JM wrote the manuscript.
} 


\section{Abstract}

14 Sequestration of plant defensive chemicals by herbivorous insects is a way to defend themselves

15 against their natural enemies. Such herbivores have repeatedly evolved bright colours to advertise

16 their unpalatability to predators, i.e. they are aposematic. This often comes with a cost. In this

17 study we examined the costs and benefits of sequestration of iridoid glycosides (IGs) by the

18 generalist aposematic herbivore, the wood tiger moth, Parasemia plantaginis. We also asked

19 whether the defence against one enemy (a predator) is also effective against another (a parasitoid).

20 We found that the larvae excrete most of the IGs and only small amounts are found in the larvae.

21 Nevertheless, the amounts present in the larvae are sufficient to deter ant predators and play a

22 role in defence against parasitoids too. However, excreting and handling these defensive plant

23 compounds is costly, leading to longer development time and lower pupal mass. Interestingly, the

24 warning signal efficiency and the amount of IGs in the larvae of $P$. plantaginis are negatively

25 correlated; larvae with less efficient warning signals contain higher levels of chemical defence

26 compounds. Our results may imply that there is a trade-off between production and maintenance

27 of coloration and chemical defence. Although feeding on a diet containing IGs can have life-

28 history costs, it offers multiple benefits in the defence against predators and parasitoids.

30 Key words bio assay, Cotesia villana, iridoid glycosides, Plantago lanceolata, warning signal 


\section{Introduction}

32 Insect herbivores in several different orders have the ability to sequester defensive compounds

33 from their host plants and use these compounds for their own defence (Duffey 1980; Nishida

34 2002). Price et al. (1980) already stated that plant-herbivore interactions both affect and are

35 affected by their relationships with the third trophic level, their natural enemies (predators,

36 parasitoids, or parasites). The interaction of plants, herbivores, and natural enemies is an active

37 field in evolutionary ecology, the role of sequestered plant defence chemicals (allelochemicals)

38 on herbivore susceptibility to parasitoids and parasitoid success has been explored in several

39 studies (e.g. Barbosa et al. 1986; Gunasena et al. 1990; Singer et al. 2004). These interactions are

40 often mediated through the sequestration of plant defence chemicals by herbivores.

41 Insects that are unpalatable do not only use their bad taste or unpleasant odour as a

42 defence, but they can advertise this defence to potential enemies, e.g. by conspicuous coloration

43 (Bowers 1993), however the cost of being conspicuous to predators can only be borne by

44 sufficiently-defended individuals (Guilford and Dawkins 1993; Lee et al. 2010; Sherratt 2002).

45 This phenomenon, known as aposematism, is widely observed across taxa and habitats, but it is

46 especially common in herbivorous species (e.g. Nishida 2002). Possession of unpalatable

47 qualities, coupled with advertisement of those qualities, has many consequences for the life

48 history features, population biology, physiology and foraging behaviour of aposematic herbivores

49 (Bowers 1993; Lindstedt et al. 2010). If both conspicuous warning signals and higher levels of

50 chemical defence are expensive to produce and they compete for the same resources, such as

51 antioxidants (e.g. Blount et al. 2009; Leimar et al. 1986), these two traits can be negatively

52 correlated. 
Sequestration of defence compounds from larval host plants may require particular

54 physiological adaptations by larvae to ingest, accumulate and store those compounds (Bowers 1992; Brattsten 1988) and this may come at a cost (e.g. lower mass, longer development time,

56 lower fecundity) (Bowers and Collinge 1992; Higginson 2011; Lindstedt et al. 2010; Ojala et al.

57 2007). Therefore, most insects that sequestrate plant secondary compounds are specialists,

58 feeding on one or a few plant species from which they acquire their defensive compounds

59 (Bowers 1988), only needing physiological mechanisms for handling specific compounds. In

60

61

62

63

64

65

66

67

addition to these specialists there are a few generalists able to sequester host-plant secondary compounds as well. The lubber grasshopper (Romalea guttata) is a generalist species and has a defensive secretion normally containing phenolics and quinones synthesized by the insect. However, when insects are reared on a restricted diet of wild onion, they sequester sulfur volatiles from the plant into their defensive secretions (Jones et al. 1989). A group of generalist moths, the Arctiinae (Family Erebidae) (Rothschild 1985) are also able to sequester plant compounds (Bowers and Stamp 1997; Rothschild et al. 1979; Singer et al. 2004; Weller et al. 1999).

Iridoid glycosides (IGs) are one group of plant secondary compounds that are sequestered by several groups of insects (Bowers 1991). In some of these species, e.g. the checkerspot butterflies (Euphydryas spp., Nymphalinae), the IGs are retained through the adult stage (Bowers 1991; Rimpler 1991; Stermitz et al. 1994; Suomi et al. 2003). This is in contrast to the buckeye butterfly, Junonia coenia (Nymphalinae), which stores IGs during larval and pupal stages but eliminates them at adult eclosion (Bowers and Collinge 1992). It is known that some Arctiine moth larvae, which are generalist feeders, also concentrate IGs (Bowers and Stamp 1997; Lampert and Bowers 2010). This suggests that the physiology of generalist Arctiine moths that sequester secondary compounds may allow them to sequester a wide variety of compounds (e.g. 
77 alkaloids Von Nickisch-Rosenegk and Wink 1993), although they may be less efficient than 78 species that sequester a single class of plant compounds (Johnson 1999).

A diversity of natural enemies (e.g. pathogens, predators and parasitoids) are the primary

80 source of mortality for larvae (Cornell and Hawkins 1995; Dempster 1983), increasing in

81 importance in older larvae and the pupal stage (Cornell et al. 1998). Studies of parasitoid-arctiine

82 larvae interaction indicate that the features that appear to be important in protecting larvae from

83 predators, such as sequestration of plant chemical compounds, bright coloration and the presence

84 of hairs or spines (Dyer 1995; Dyer 1997; Lindstedt et al. 2008), may not be as effective against

85 parasitoids (Gentry and Dyer 2002; but see Singer et al. 2009). Sequestration of plant chemicals may even be beneficial for parasitoids, because they live in a chemically protected larva and are

87 thus protected themselves as well (Gauld and Gaston 1994). It has also been shown that 88 allelochemicals in the host diet weaken the immune system of the herbivore (Smilanich et al. 2009), this would benefit the developing parasitoids by enabling them to reallocate metabolic 90 energy from immunosuppression or avoidance to growth and development (Kraaijeveld and

91 Godfray 1997; Ojala et al. 2005). On the other hand, host plant secondary metabolites can be 92 harmful for insects, and detoxification can be energetically costly (Berenbaum and Zangerl 1993;

93 Després et al. 2007), which results in lower host quality for the parasitoid (Smilanich et al. 2009).

94 Furthermore, if the parasitoid cannot avoid or tolerate the sequestered plant chemicals, they may 95 have detrimental effects for them (Gauld and Gaston 1994).

In this study we tested the effects of plant defence chemicals in a multitrophic system, 97 starting with differences in the levels of defence chemicals in the plant, sequestered via the 98 aposematic larva. We examined the ability of the generalist Arctiine moth (P. plantaginis) to 99 sequester IGs from a diet containing only Plantago lanceolata and the effects of different 100 amounts of IGs in this diet on its performance. We knew from a previous study that these 
caterpillars are able to sequester small amounts of IGs (Lindstedt et al. 2010) and it is know from 102 other Arctiine moths that they can sequester plant defence chemicals (Bowers and Stamp 1997; 103 Rothschild et al. 1979; Weller et al. 1999). Further we assumed that higher levels of IGs in their 104 diet would have more negative effects on their performance. Second we tested if chemical 105 defence (sequestered IGs) was affective against predators (ants): we performed a bioassay 106 experiment to determine the deterrent effects of the IGs aucubin and catalpol on ants, both 107 compounds separate and combined, and tested whether extracts from larvae that had eaten a diet 108 that contained IGs were less palatable for ants than larvae with an IG-free diet. Last we measured 109 the parasitism rate of larvae in their natural environment in a field experiment. The parasitoid wasps from the field experiment were used under lab conditions to examine the effect of host 111 plant species on parasitoid performance.

\section{Material and Methods}

114 Study Organism. The generalist P. plantaginis (family Erebidae, subfamily Arctiinae; formerly 115 Arctiidae) has warningly coloured larvae and adults and is unpalatable to several vertebrate and 116 invertebrate predators (Lindstedt et al. 2008; Nokelainen et al. 2012). Their natural diet consists 117 mainly of the host plants Plantago lanceolata (narrow leaf plantain), Plantago major (broad leaf 118 plantain), Rumex oblongifolius (bluntleaf dock), Senecio vulgaris (Groundsel), Hieracium 119 pilosella (mouse-ear hawkweed), Vaccinium myrtillus (myrtle blueberry), Taraxacum 120 campylodes and T. officinale (dandelion) (Bellman 2007; Lindsey 2006; Robinson et al. 2010 and

121 own obeservation). The larvae are hairy in all instars, but their colouration changes from (cryptic)

122 greenish grey in the first two instars to orange-black in the third instar and onwards. They pupate 123 after five to seven instars (Ojala et al. 2007). In Finland this species has one generation per year, 
124 and overwinters as a larva. In the laboratory, $P$. plantaginis can produce two to three generations 125 of which the second or third generation overwinters.

127 plantaginis larvae (Ojala et al. 2007) and is highly heritable (Lindstedt et al. 2009). In the 128 laboratory we have artificially selected for the extremes of this signal size continuum and created 129 two selection lines, small and large signal (for details see Lindstedt et al. 2009). For our 130 experiments we used larvae derived from these two selection lines with small (3 or less body 131 segments orange) and large orange signal ( 5 or more body segments orange). A previous study by 132 Lindstedt et al. (2008) showed that the predator Parus major (great tit) learns to avoid larvae with 133 a large signal faster than larvae with a small signal. The orange patch against a black body had a 134 high signal value for predators. The avoidance learning rate was higher when larvae had an 135 orange patch than when larvae were without one. The size of the orange signal also mattered. A 136 large patch enhanced the avoidance learning rate of avian predators, as shown by a longer latency 137 to attack (Lindstedt et al. 2008).

Plantago lanceolata is a perennial herb with a worldwide distribution and high ecological amplitude (Sagar and Harper 1964). The distribution ranges of $P$. lanceolata and $P$. plantaginis 140 overlap, and P. lanceolata is a known host plant of $P$. plantaginis larvae (Bellman 2007; Pabis 141 2007). The main defence compounds of $P$. lanceolata are the IGs, aucubin and catalpol (Duff et 142 al. 1965), they play an important role in plant-insect interactions as chemical defence compounds. 143 Many herbivores are known to sequester them and use them for their own defence against natural 144 enemies (Camara 1997; Dyer and Bowers 1996; Nieminen et al. 2003; Willinger and Dobler 145 2001).

146 In wild populations, the IG levels of $P$. lanceolata range from undetectable to $12 \%$ of 147 their dry weight in the youngest leaves (Bowers et al. 1992; Bowers and Stamp 1992). Previous 
studies have identified plant age as an important intrinsic factor affecting $P$. lanceolata chemistry

149 (e.g. Barton 2007; Bowers and Stamp 1993; Fuchs and Bowers 2004); and these ontogenetic trajectories in IG production significantly vary among both maternal families and populations

151 (Barton 2007; Bowers and Stamp 1993) and are highly heritable (Marak et al. 2000). The plants 152 used for this study were offspring from plants derived from an artificial selection experiment in 153 which plants were selected on the basis of high and low concentration of total leaf IGs for four 154 generations (for details see Marak et al. 2000).

Sequestration and performance experiment

157 To determine if $P$. plantaginis larvae are able to take up IGs from their diet, and to see if different 158 levels of IGs in their diet have on effect on their performance, we conducted a sequestration 159 experiment. For this experiment we used larvae from both selection lines, due to availability only 10 families from the small signal selection line and 20 families from the large signal selection 161 line were used. The larvae were fed six different diets. Each diet consisted of plant clones from one P. lanceolata genotype. All different genotypes used differed significantly in their IG levels 163 (Table 1). In total we used 60 larvae from the small selection line (10 larvae per diet treatment) and 120 larvae from the large selection line (20 larvae per diet treatment). The plants used for the diets were grown in a greenhouse at the University of Jyväskylä. Larvae were reared individually in a petri-dish and given fresh leaves every day. We measured their development time, signal size

167 (number of orange segments) and pupal mass. We froze 3-8 larvae per diet for analyses with high 168 performance anion exchange chromatograph with pulsed amperometric detection (HPAEC-PAD). 169 Furthermore, we collected samples of their diet and their droppings during the experiment for 170 HPAEC-PAD analyses (see chemical analyses). The IGs (aucubin and catalpol) of three random 171 samples per diet were measured at two points in time. We also collected the droppings of each 
172 larva for IG analyses at these two time points (one at the start of the experiment and the second 173 one month later).

175 Bioassay experiment with ants

176 In a previous study (Lindstedt 2008) P. plantaginis larvae were attacked by ants, but not

177 preferred and none of the larvae were killed. With the bioassay we wanted to exclude all other 178 factors to separate the chemical defence from other defences (e.g. hairiness, warning coloration). 179 One common bioassay method for assessing deterrence of specific toxins is to offer sugar 180 solutions laced with animal or plant extracts to predaceous ants (Dyer et al. 2003a; Hare and 181 Eisner 1993; Molleman et al. 2012). Two different bioassay experiments were conducted, one 182 experiment with pure IG assays (aucubin and catalpol), and one with bioassays made from larvae 183 that either had IGs in their diet or not (non IG larvae). Both experiments were performed in the 184 vicinity of ant nests in Kuokkala, Jyväskylä (E3435985, N 6903199). The test site was pine 185 dominated forest with some deciduous trees. All tests were performed in August 2008 (pure IGs) 186 and August 2009 (larval extractions), in sunny to half cloudy weather when ants were active.

187 For the pure IG experiment we made three IG solution of $0.02 \%$ (which is comparable 188 with the amount of catalpol found previously in P. plantaginis larvae (Lindstedt et al. 2010), 189 aucubin, catalpol or both compounds present. All solutions were made in a $0.1 \mathrm{M}$ sugar water 190 solution. As control we used a $0.1 \mathrm{M}$ sugar water solution without adding any IGs. The study was 191 conducted at 5 different ant nests which were not connected to each other. A drop of $200 \mu l$ test 192 solution was put on a leaf at an ant path (at least $1.5 \mathrm{~m}$ from the nest). We measured how long an 193 individual ant drank from the solution. When it finished drinking it was taken away in a petri194 dish, so we would not measure the same individual twice, and the next ant to observe was chosen. 
We continued this until we had measurements 20 ants per treatment per nest, including the 196 control treatment. Poitout and Bues (1974) by leaving out ascorbic acid and formaldehyde and adding $0.5 \%$ Vanderzant vitamin mixture for insects). Half of the larvae ate diet that contained dried and ground $P$. lanceolata leaves (IG diet) and the other half ate the same diet without the added leaves (non IG). After the larvae reached 100mg they were starved for 24 hours, to make sure their gut was empty, after which they were frozen and freeze dried. The ground larvae were 203 extracted in methanol $\left(1 \mathrm{ml}\right.$ methanol/60mg larva) at $15^{\circ} \mathrm{C}$ overnight. The solution was filtered over a Whatmann \#4 filter paper and $0.2 \mathrm{ml}$ solution was added to $4.5 \mathrm{ml} 20 \%$ sugar water. As a control we had $0.2 \mathrm{ml}$ pure methanol with $4.5 \mathrm{ml} 20 \%$ sugar water solution. The solutions were also tested for free amino acids (see chemical analyses).

In this experiment we tested 10 ant nests. Every nest was tested three times per test208 solution. At the same time $200 \mu \mathrm{l}$ of test solution (IG or non IG) and $200 \mu 1$ control solution 209 (sugar water) were put on a leaf collected from the surroundings of the ant nest. Because of the 210 high abundance of ants, instead of following one individual ant the total number of ants drinking 211 from a solution was measured. Timing was started when the first ant arrived and drank from the 212 solution. The duration of each test was eight minutes. After every minute the leaf was 213 photographed, so the number of ants drinking from each solution could be counted. After eight 214 minutes the ants and leaf were removed from the test spot. As a measurement we took the 215 average amount of ants drinking from the solution during these eight minutes. We also measured 216 the ant activity per nest, for one minute all ants passing by on the test route were counted, prior to 217 each experiment. 
220 To examine larval parasitism rate of $P$. plantaginis in the field, we conducted a field experiment

221 on the Åland islands where this species naturally occurs (Leraut 2006). The experiment was 222 conducted in summer 2008 (end of May to first week of June) when P. plantaginis larvae are 223 naturally occurring in the field. We put mass-reared (50-100 larvae per bucket) post diapause 224 larvae from both signal selection lines on 48 potted $P$. lanceolata plants outside in the field (10 225 larvae per plant), on six different locations (total of 480 larvae). The plants were covered with a 226 mesh cloth that prevented the larvae from leaving the plant, but allowed parasitoids to parasitize 227 the larvae. They were left in the field until the first larva started to pupate (after 13-14 days), to 228 obtain only the larval parasitoids. We reared all larvae until an adult butterfly or parasitoid 229 egressed. We noted the signal size of the larva, development time, sex and parasitism success. The emerged parasitoid wasps were mated and used in the laboratory to parasitize 33 randomly selected laboratory reared $P$. plantaginis larvae from both selection lines. The larvae 232 were fed Taraxcum officinale, one of their natural host plants (Bellman 2007), from the field. We 233 measured the clutch size, development time and sex-ratio of the parasitoids and used them again 234 to parasitize 139 larvae (from 11 available families, 2 from the large signal selection line, and 9 235 from the small signal selection line) that were fed $P$. lanceolata leaves. The same parameters 236 were measured as in the previous generation.

239 HPAEC-PAD- All larvae were frozen at $-80^{\circ} \mathrm{C}$ and freeze dried, weighed, then ground by hand in 240 an Eppendorf tube. Ground material was extracted in $5 \mathrm{ml} 7 \% \mathrm{MeOH}$ and left overnight. The 241 crude extract was filtered on a Whatman \#4 filter paper and the filtrate was diluted in 1:5 ratio 242 with $7 \% \mathrm{MeOH}$. The concentrations of aucubin and catalpol were analysed by HPLC using a 
243 Bio-LC (Dionex Corp., Sunnyvale, USA) equipped with a GS50 gradient pump, a CarboPac PA 24420 guard $(3 \times 30 \mathrm{~mm})$ and analytical column $(3 \times 150 \mathrm{~mm})$. Detection was performed with an ED 24550 PAD equipped with a disposable gold electrode using carbohydrate Waveform A. Isocratic 246 elution with $70 \mathrm{mM} \mathrm{NaOH}$ (flow rate $0.25 \mathrm{ml} / \mathrm{min}$ ) was used for the separation. Columns and 247 disposable gold electrode were cleaned after each sample with alkaline (100 mM NaOH) 300 $248 \mathrm{mM}$ sodium acetate solution. Retention times were $4.1 \mathrm{~min}$. and $6.3 \mathrm{~min}$. for aucubin and catalpol, 249 respectively. Concentrations were analysed using Chromeleon Client version 6.50 SP10a Build 2501065 (Dionex Corp., Sunnyvale, USA).

251 For the droppings we used the same method as for the larvae, except that we did the 252 extraction in $10 \mathrm{ml} \mathrm{70 \%} \mathrm{MeOH}$ and diluted the samples in 1:10 ratio with Milli-Q water (internal 253 resistance $\geq 18.2 \mathrm{M} \Omega \cdot \mathrm{cm}$; Milli-Q Plus, Millipore, Bedford, MA, USA) and did not grind the 254 samples beforehand. For the measurements of the diets, we took randomly selected leaves from 255 several plants of the same genotype per diet, and froze them at $-80^{\circ} \mathrm{C}$. After freeze drying the 256 leaves were ground with a Mikro-dismembrator U (B.Braun Biotech International, Allentown, 257 PA). For the extraction we followed the same method as for the droppings, only we took $25 \mathrm{mg}$ 258 of ground leaf material.

$U V$-spectrophotometry- The bioassay larva solutions were analysed spectrophotometrically to 261 determine the amount of free amino acids in the solutions. An OPA-reagent solution was made by combining $25 \mathrm{ml}$ of $100 \mathrm{mM}$ sodium tetraborate solution, $2.5 \mathrm{ml} 20 \%$ sodium lauryl sulphate 263 water solution, $40 \mathrm{mg}$ o-phtalaldehyde (dissolved in $1 \mathrm{ml}$ of $\mathrm{MeOH}$ ) and $100 \mu \mathrm{l} \beta$ 264 mercaptoethanol and the mixture was diluted to a final volume of $50 \mathrm{ml}$ with Milli-Q. The larva 265 test solutions were mixed in 1:20 ratio with OPA solution in $3 \mathrm{ml}$ glass tubes. The absorbance of 266 the solutions was measured at $340 \mathrm{~nm}$ by a Beckman DU 640 (Beckman Instruments Inc., 
267 Fullerton, CA, USA) spectrophotometer. Sample solutions were compared with the control 268 solution ( $\mathrm{MeOH}$ with sugar water), and solutions with known amount of L-leucine (a standard 269 amino acid with two concentration levels).

271 Statistical analyses

272 All statistical analyses were performed using the statistical program PASW Statistics 18 (SPSS

273 Inc., Chicago, Illinois, USA). Data were controlled for homogeneity and normality.

274 We used analysis of variance (ANOVA) with Post Hoc Tukey to test for differences in IG 275 content (dependent variable) between the six diets/genotypes (fixed factor) at both measuring 276 times, used in the performance and sequestration experiment. For the sequestration and 277 performance experiment we used independent $t$-tests to compare between the diets in time, and to 278 test for differences between larval selection line (small signal vs large signal) and the amount of 279 IGs sequestered by the larvae, a paired t-test was used to test for differences between the 280 compounds (aucubin vs catalpol) sequestered by the larvae. A bivariate correlation was used to 281 analyse if the amounts of IGs in the diets were related to the amounts in the larval droppings and 282 to analyse the relation of signal size of the larvae to their level of sequestered catalpol.

283 For the bioassay experiment, ANOVA's were used to test for differences between the 284 treatments and ant nests. Drinking time was the dependent factor, treatment the fixed factor and 285 nest was included as random factor.

In the parasitism experiments, independent $t$-tests were used to look at the differences in 287 development time between male and female wasps. The analyses of the larvae that were not 288 successfully parasitized, reared on $T$. officinale and the P. lanceolata diet, were performed 289 separately for males and females, because there was an interaction of sex $\times$ diet. We used 
290 independent $t$-test to determine the differences of the performance parameters between the two 291 diets.

\section{Results}

294 Sequestration and performance

295 There was a significant interaction between the IGs in the diets and the time of harvest $\left(F_{5,25}=\right.$ $29661.037, P<0.001$ ), therefore we analysed the diets separately per harvest time (start of the 297 experiment and one month later). The six diets differed significantly in their amounts of aucubin, 298 catalpol and total amount of IGs (aucubin+catalpol) at the start of the experiment and also one 299 month later (Table 1). The average amount of total IGs in the diets at the start of the experiment $300 \quad(1.35 \%$ of the dry weight) was significantly lower than the amount measured one month later $301 \quad(3.36 \%$ of the dry weight; $t$-test: $t=-2.790, \mathrm{df}=35, P=0.008)$.

Trace amounts of IGs were detected in the larvae and the amount of catalpol was 303 significantly higher than the amount of aucubin $(0.047 \mathrm{vs} 0.012 \%$ of dry weight; $t$-test $t=5.311$, 304 $\mathrm{df}=27, P<0.001)$. These trace amounts were not correlated $(P>0.05)$ with the amount of IGs 305 in the different diets at both measuring times (Fig. 1). However, larvae from the small signal 306 selection line had significantly higher amounts of catalpol in their bodies, than larvae from the 307 large signal selection line ( $t$-test $t=2.297, \mathrm{df}=26, P=0.030$; Fig 2A). This amount of catalpol 308 was also significantly negatively correlated with the absolute signal size of the larvae $(r=0.517$, 309 $P=0.004$ ), significantly more catalpol was detected in larvae with a smaller orange patch (Figure 310 2B).

To see if there was a correlation between the amount of IGs in the larval diet, and the amount larvae would excrete directly, we measured the amount of IGs in their droppings. The 
314 the first month of the experiment $(r=0.417, P<0.001$; Figure 3A), however this association 315 disappeared in the second month of the experiment, and also the total amount of IGs that was excreted decreased $(0.38 \%$ vs. $0.056 \%$ of the dry weight; $t$-test $t=5.812, \mathrm{df}=113, P<0.001$, Figure 3B), while the total amount of IGs in the diet increased (see above).

The diet had no effect on the size of the orange patch of the larvae or on the developmental time or their pupal weight. However, selection line did have an effect on the

performance measurements of the larvae. Larvae from the small selection line had a longer larval development time $\left(F_{1,22}=4.324, P=0.049\right)$ than larvae from the large selection line, there was no effect of selection line on the pupal development time. There was no difference in the other performance measurements between the selection lines.

Bioassay experiment

In the pure IG-treatment there was a significant difference between the treatments $\left(F_{3,424}=4.016\right.$, $P=0.008)$. Ants drank longer from the pure sugar solution $(86.14 \pm 7.27 \mathrm{sec})$ than from the test solutions $(57.85 \pm 6.46 \mathrm{sec}, 60.75 \pm 8.32 \mathrm{sec}, 58.59 \pm 8.32 \mathrm{sec}$, aucubin, catalpol or both IGs respectively, Fig. 4). The compounds of the test solution had no effect on the drinking time, difference in the time ants drank from the solutions among the different ant nests $\left(F_{4,424}=5.738\right.$, $P<0.001)$, but no interaction between nests and treatment $\left(F_{12,412}=1.44, P=0.158\right)$.

In the larva IG-treatment there was a significant effect of treatment $\left(F_{1,49}=8.299, P=\right.$ $0.006)$ and ant nest $\left(F_{9,49}=14.378 ; P<0.001\right)$ on the total number of visits (corrected for the amount of ants walking on the ant path): more ants visited the IG-free solution $(96.97 \pm 11.4$ ants) 336 than the IG-solution extracted from the larvae $(78.10 \pm 9.9$ ants $)$. However, ants preferred the 
the treatment solutions $(87.53 \pm 7.59$ ants $)$, than from the control sugar solutions $(36.72 \pm 3.69$ ants; $t$-test $t=10.306, \mathrm{df}=59, P<0,001)$. Because this result was not expected we hypothesized

that the larvae contain nutrients (e.g. proteins) that are favourable for ants and thus we measured

341 the free amino acids present in the different solutions. There were significantly fewer amino acids

342 present in the control sugar solution than in the test solutions $\left(F_{2,10}=12.593, P=0.002\right)$, there

343 was no difference between the two larval test solutions.

\section{Parasitism experiments}

346 Field - Of the 480 larva that were placed in the field, 398 were brought back to the laboratory, 347 the other ones died or were lost in the field. Of these 398 only two larvae were parasitized. One 348 (large selection line, signal size 7) was parasitized by the Tachinid, Carcelia lucorum (Identified 349 by Liekele Sijstermans), one fly emerged from this larva. The other larva (small selection line, 350 signal size 3) was parasitized by the gregarious Braconid endoparasitoid Cotesia villana (Reinard) 351 (Identified by Mark Shaw). Twenty one wasps emerged from this larva, 16 females and 5 males. 352 These offspring were used to artificially parasitize P. plantaginis larvae in the laboratory.

353 Laboratory - There was a difference in the successful parasitism rate between the larval diets (3 $354 \%$ P. lanceolata vs $28 \%$ T. officinale) and more wasps hatched when larvae were fed $T$. 355 officinale as diet compared to P. lanceolata diet. From the 33 larvae reared on Taraxacum 356 officinale diet 8 died, 18 pupated and 7 were successfully parasitized by C. villana. The 357 parasitoids had an average clutch size of $16( \pm 4.61)$ per larva, with a hatching success of $88.9 \%$ 358 and a sex ratio (males/total emerged) of $69.32 \%( \pm 13.32)$. The males had a significantly longer 359 larval development time than female wasps ( $t$-test $t=-3.283$, $\mathrm{df}=93, P=0.002$ ). However, 360 males had a shorter pupal development time ( $t$-test $t=-6.508, \mathrm{df}=93, P<0.001)$, therefore there 361 was no difference in the total development time between males and females, nor in the weight of 
their cocoons. From the 139 larvae reared on P. lanceolata, 44 died, 92 pupated and only 3 larvae

363 were successfully parasitized, with an average clutch size of $10( \pm 2.65)$ and a hatching success 364 of $43.3 \%$ (only females emerged).

365 When we compared the larvae that were not successfully parasitized and developed into 366 adults on the two different diets, we found that pupa from the T. officinale diet were significantly 367 heavier than pupa reared on $P$. lanceolata both for females and males $(t$-test $\bigcirc t=7.372, \mathrm{df}=45$, $368 P<0.001 ; \delta t=2.925, \mathrm{df}=51, P=0.005)$, the same was true for the adult weight of the moths $369(t$-test $q t=6.700, \mathrm{df}=45, P<0.001 ; \widehat{\partial} t=4.281, \mathrm{df}=53, P=0.003)$. Also larvae reared on $T$. 370 officinale diet developed faster from pupa to adult in both females and males, compared to larvae 371 reared on $P$. lanceolata diet $\left(t\right.$-test $q t=-5.668, \mathrm{df}=45, P<0.001$; ${ }^{\lambda} t=-11.563$, df $=51, \mathrm{P}<$ $3720.001)$.

\section{Discussion}

375 The role of plant chemistry is important in many ecological and evolutionary hypotheses 376 addressing plant-insect-natural enemy relationships, species diversity and community dynamics 377 (Price et al. 1980; Speed et al. 2013). Especially in herbivorous insects that are capable of 378 sequestering or storing plant defence chemicals, plant chemistry plays a role in all trophic 379 interactions (Ode 2006).

380 In this study we only found trace amounts of the plant allelochemicals present in the 381 larvae. This suggest that $P$. plantaginis detoxifies or excretes the plant defence chemicals rather 382 than sequestrates them (see also Lindstedt et al. 2010). This was also confirmed by the positive 383 correlation between the amount of IGs present in the diets of the larvae and in their droppings.

384 However, this association was not present anymore later in the experiment, when there were less 
IGs present in the excretion products of the larvae, but more in their diets. This could suggest a higher uptake of the plant chemicals by the larvae later in their development. Unfortunately, we only measured the IGs present in the larvae at one time point, so we cannot determine if there would be a more efficient uptake of IGs by the larvae later in time. Development-dependent sequestration of IGs was found for the sawfly species Athalia cordata and A. circularis (Opitz et al. 2010). The concentration of IGs increased significantly over time in the hemolymph of $A$. cordata larvae reared on P. lanceolata and in the hemolymph of A. circularis fed on Veronica beccabunga.

Parasemia plantaginis seems to take up IGs selectively. We detected significantly more catalpol than aucubin in the larvae, although this ratio was the opposite in the diets fed to the larvae. Either there was a higher sequestration efficiency of catalpol or a more efficient excretion of aucubin. This same result has been found for another Arctiine moth (Spilosoma congrua) feeding on P. lanceolata (Bowers and Stamp 1997). The higher ratio of catalpol to aucubin in the larval samples, may also be due to an epoxidation of the precursor aucubin into catalpol (Opitz et al. 2010).

That larvae from the small signal selection line had significantly higher amounts of 401 catalpol present than larvae from the large signal selection line, may be due to their prolonged 402 larval development time. They just had more time to accumulate catalpol from their diet, or they 403 ingested more because they ate more food. Another explanation could be that the higher level of catalpol present reflects the trade-off between the warning signal and chemical defence, because 405 the production of more melanin coloration (small signal selection larvae) is costly (Ojala et al. 406 2007) and larvae with more melanin synthesis may have fewer resources left for excretion of IGs.

407 On the other hand, it is possible that more melanic larvae are able to compensate their less 408 efficient warning signal by containing more defensive toxins (Darst et al. 2006; Leimar et al. 
1986; Speed and Ruxton 2005). In earlier study by Friman et al. (2009) more melanic $P$.

410 plantaginis larvae had better immunological defence against certain pathogens. Zhang et al.

411 (2012) found that more melanin larvae were able to recover from infections of Serratia

412 marcescense. It is possible that melanic forms are also better in tolerating the auto toxicity costs

413 of IG compounds.

414 Although only relatively small amounts of IGs were present in the larvae, these seem to

415 be sufficient to be a deterrent for a generalist ant predator. It is know from field experiments with

416 six different species of ants (Hymenoptera, Formicida) that they drink less Catalpa speciosa

417 nectar, which contains IGs (e.g. catalpol), than a sucrose solution of identical sugar concentration.

418 The ants that did drink for the C. speciosa nectar, developed behavioural abnormalities, such as

419 erratic movements, loss of balance or loss of locomotion (Stephenson 1981). In our study fewer

420 ants drank from the solutions made from larvae fed diets that contained IGs than from the

421 solution of the control diet larvae. An unexpected result was that the ants preferred the larva

422 solutions above the control sugar solutions. This was probably due to the extra nutrients available

423 in the larva's solutions (Lanza 1988). The test solutions contained significant more free amino

424 acids than the control sugar solution. The pure IG solutions clearly show a deterrent effect of both

425 IGs for ants. There was no significant difference between the deterrence of aucubin or catalpol,

426 and there was no synergistic effect when both IGs were present in the same solution (in contrast

427 to Dyer et al. 2003b; Richards et al. 2010).

428 Parasitism rate of P. plantaginis in the field was very low, only two out of the 480 larvae

429 that were put in the field were parasitized. This can be due to low density of parasitoids in the

430 field, an effective larval defence or low host suitability. In the laboratory we found that the

431 endoparasitoid wasp C. villana was capable of parasitizing P. plantaginis larvae successfully. 
432 The difference we find between the two diet treatments could also be caused by a difference in 433 the quality of the parasitoids due to inbreeding. All wasps used in these experiments came from a 434 single brood. The F1 generation was used for the T. officinale diet and the F2 generation for the $P$. 435 lanceolata diet, therefore we cannot distinguish between diet or generation effects. However, 436 larvae reared on a diet of $T$. officinale were parasitized significantly more successfully than the 437 larvae reared on a diet of $P$. lanceolata. Another study of $P$. plantaginis found that survival of 438 Serratia marcescense infected larvae was significantly higher among larvae that fed Plantago 439 major than T. officinale (Zang et al. 2012). Plantago major also contains IGs although their 440 concentrations are lower than in P. lanceolata (Reudler Talsma et al. 2008). In the present study, 441 the successful egression was much higher on the non-IG diet. This could be due to the uptake of 442 IGs from the $P$. lanceolata diet, which could work as a defence for the $P$. plantaginis larvae 443 against the parasitoids. Another possible explanation is that the quality of the host is much lower, 444 due to costs of the chemically defended diet (Lindstedt et al. 2010; Ode 2006), and does not 445 support the development of the parasitoids. Studies in other Arctiinae show diet affecting 446 parasitoid success. Larvae of Platyprepia virginali that feed on lupine have a reduced chance of 447 being parasitized (indicated by dissection results), but a greater chance of surviving parasitism 448 when feeding on hemlock. Therefore, selection should favour multiple host use by woolly bears 449 (English-Loeb et al. 1993). Singer et al. (2004) found that for the Arctiinae caterpillar Estigmene 450 acrea a pure Viguiera dentata diet provides superior growth performance over a pure Senecio 451 longilobus or mixed diet in the absence of parasitism. However, when parasitism risk is at least 452 moderate, the mixed diet provides a survival advantage over the pure diets of Viguiera or 453 Senecio, showing trade-offs between growth and enemy-free space. Recently, it has been found 454 that many herbivores can adaptively modify their food intake and choice of diet when risk of 
455 infection is high (prophylactic consumption) or infection has already happened (therapeutic self456 medication) and improve their chance of survive (see rev. Abbott 2014).

458 parasitized reared on $P$. lanceolata diet compared to these larvae reared on $T$. officinale diet; they 459 had lower pupal and adult mass, which is correlated with their fecundity (Honek 1993), and a 460 longer development time. Besides differences in plant defence chemicals, it is also possible that 461 the two host plant species differ nutritionally, which can affect the performance of the larvae and 462 also their immunological defence (Singer et al. 2014)

463 Overall, this study shows that P. plantaginis larvae are able to take up some amount of the 464 defensive compounds from their diet, which is sufficient as a deterrent against generalist 465 predators and might be a good defence against parasitoids as well. It is worthwhile to note that 466 because $P$. plantaginis is a polyphagous species (Marttila et al. 1996), they probably exploit other 467 defence chemicals in their diet as well as IGs. If there are differences in the sequestration and 468 excretion efficacy among these chemicals, defence and its efficacy can vary as well. Different 469 chemical resources may provide defence during different stages of development, and may be 470 effective against different enemies or may work additively or synergistically against a given 471 enemy at a given developmental stage (Mason and Singer 2015). In this study the consumption of 472 a diet which contains defensive chemicals comes at a cost, by decreasing the performance of the 473 herbivores. Finally, it is possible that variation in the warning signal efficiency in this species 474 could be maintained due to compensating effects of higher amount of defensive toxins in larvae 475 with less efficient signals. Further studies are needed to investigate the development-dependent 476 efficiency of sequestration of $P$. plantaginis and the effect of host plant use in the field to their 477 rate of predation and parasitism. 


\section{Acknowledgements}

479 We would like to thank Kaisa Suisto for rearing the P. plantaginis larvae used in the experiments

480 and Emily Burdfield-Steel and an anonymous reviewer for very helpful comments on previous

481 versions of the manuscript. Further we thank Nåtö Biological Station for providing 482 accommodation during the field work. This research was funded by the Centre of Excellence in

483 Biological Interactions and Academy of Finland grant \#SA- 128528 and 218372. 


\section{References}

485
Abbott J (2014) Self-medication in insects: current evidence and future perspectives. Ecological Entomology 39: 273-280

Barbosa P, Saunders JA, Kemper J, Trumbule R, Olechno J, Martinat P (1986) Plant allelochemicals and insect parasitoids. Effects of nicotine on Cotesia congregata (Say) (Hymenoptera, Braconidae) and Hyposoter annulipes (Cresson) (Hymenoptera, Ichneumonidae). Journal of Chemical Ecology 12:1319-1328

Barton KE (2007) Early ontogenetic patterns in chemical defense in Plantago (Plantaginaceae): genetic variation and trade-offs. American Journal of Botany 94:56-66

Bellman H (2007) Vlinders, rupsen en waardplanten. Tirion Uitgevers, Baarn

Berenbaum M, Zangerl AR (1993) Furanocoumarin metabolism in Papilio polyxenes: biochemistry, genetic variability, and ecological significance. Oecologia 95:370-375

Blount JD, Speed MP, Ruxton GD, Stephens PA (2009) Warning displays may function as honest signals of toxicity. Proceedings of the Royal Society B 276:871-877

Bowers MD (1988) Chemistry and coevolution: Iridoid glycosides, plants and herbivorous insects. In: Spencer K (ed) Chemical Mediation of Coevolution. Academic Press, New York, pp 133-165

Bowers MD (1991) Iridoid glycosides. In: Rosenthal GA, Berenbaum MR (eds) Herbivores: their interactions with secondary plant metabolites. Academic Press, San Diego, pp 297-325

Bowers MD (1992) Unpalatability and the cost of chemical defense in insects. In: Roitberg BD, Isman MB (eds) Chemical Ecology of Insects: an Evolutionary Approach. Chapman and Hall, New York, pp 216-244

Bowers MD (1993) Aposematic caterpillars: life-styles of the warningly colored and unpalatable. In: Stamp NE, Casey TM (eds) Caterpillars: ecological and evolutionary constraints on foraging. Chapman \& Hall, New York, pp 331-371

Bowers MD, Collinge SK (1992) Fate of iridoid glycosides in different life stages of the buckeye, Junonia coenia (Lepidoptera, Nymphalidae). Journal of Chemical Ecology 18:817-831

Bowers MD, Collinge SK, Gamble SE, Schmitt J (1992) Effects of genotype, habitat, and seasonal-variation on iridoid glycoside content of Plantago lanceolata (Plantaginaceae) and the implications for insect herbivores. Oecologia 91:201-207

Bowers MD, Stamp NE (1992) Chemical variation within and between individuals of Plantago lanceolata (Plantaginaceae). Journal of Chemical Ecology 18:985-995

Bowers MD, Stamp NE (1993) Effects of plant-age, genotype, and herbivory on Plantago performance and chemistry. Ecology 74:1778-1791

Bowers MD, Stamp NE (1997) Fate of host-plant iridoid glycosides in lepidopteran larvae of Nymphalidae and Arctiidae. Journal of Chemical Ecology 23:2955-2965

Brattsten LB (1988) Enzymic adaptations in leaf-feeding insects to host-plant allelochemicals. Journal of Chemical Ecology 5:1919-1939

Camara MD (1997) Predator responses to sequestered plant toxins in buckeye caterpillars: are tritrophic interactions locally variable? Journal of Chemical Ecology 23:2093-2106

Cornell HV, Hawkins BA (1995) Survival patterns and mortality sources of herbivorous insects: some demographic trends. American Naturalist 145:563-593

Cornell HV, Hawkins BA, Hochberg ME (1998) Towards an empirically-based theory of herbivore demography. Ecological Entomology 23:340-349

Darst CR, Cummings ME, Cannatella DC (2006) A mechanism for diversity in warning signals: consipicuouness versus toxicity in poison frogs. Proceedings of the National Academy of Sciences of the United States of America 103:5852-5857 
Dempster JP (1983) The natural control of populations of butterflies and moths. Biol Rev 58:461-481 Trends in Ecology \& Evolution 22:298-307

Duff RB, Bacon JSD, Mundie CM, Farmer VC, Russell JD, Forrester AR (1965) Catalpol and methylcatalpol: naturally ocurring glycosides in Plantago and Buddleia species. Biochemical Journal 96:1-5

Duffey SS (1980) Sequestration of plant natural products by insects. Annual Review of Entomology 25:447-477

Dyer LA (1995) Tasty generalists and nasty specialists? Antipredator mechanisms in tropical lepidopteran larvae. Ecology 76:1483-1496

Dyer LA (1997) Effectiveness of caterpillar defenses against three species of invertebrate predators. Journal of Research on the Lepidoptera 34:48-68

Dyer LA, Bowers MD (1996) The importance of sequestered iridoid glycosides as a defense against an ant predator. Journal of Chemical Ecology 22:1527-1539

Dyer LA, Dodson CD, Gentry G (2003a) A bioassy for insect deterrent compounds found in plant and animal tissues. phytochemical analysis 14:381-388

Dyer LA et al. (2003b) Synergistic effects of three Piper amides on generalist and specialist herbivores. J Chem Ecol 29:2499-2514

English-Loeb GM, Brody AK, Karban R (1993) Host-plant-mediated interactions between a generalist folivore and its tachinid parasitoid Journal of Animal Ecology 63:465-471

Friman V-P, Lindstedt C, Hiltunen T, Laakso J, Mappes J (2009) Predation on multiple trophic levels shapes the evolution of pathogen virulence. PLoS ONE:e6761

Fuchs A, Bowers MD (2004) Patterns of iridoid glycoside production and induction in Plantago lanceolata and the importance of plant age. Journal of Chemical Ecology 30:1723-1741

Gauld ID, Gaston KJ (1994) The taste of enemy-free space: parasitoids and nasty hosts. In: Hawkins BA, Sheehan W (eds) Parasitoid community ecology. Oxford University Press, New York, pp 279-299

Gentry G, Dyer LA (2002) On the conditional nature of neotropical caterpillar defenses against their natural enemies. Ecology 83:3108-3119

Guilford T, Dawkins MS (1993) Are warning colors handicaps? Evolution 47:400-416

Gunasena GH, Vinson SB, Williams HJ (1990) Effects of nicotine on growth, development, and survival of the tobacco budworm (Lepidoptera, Noctuidae) and the parasitoid Campoletis sonorensis (Hymenoptera, Ichneumonidae). Journal of Economic Entomology 83:1777-1782

Hare JF, Eisner T (1993) Pyrrolizidine alkaloid deters ant predators of Utetheisa ornatix eggs-effects of alkaloid concentration, oxidation-state, and prior exposure of ants to alkaloid-laden prey. Oecologia 96:9-18

Higginson AD, Delf J, Ruxton, GD, Speed, MP (2011) Growth and reproductive costs of larval defence in the aposematic lepidopteran Pieris brassicae. Journal of animal Ecology 80:384-392

Honek A (1993) Intraspecific variation in body size and fecundity in insects: a general relationship. Oikos 66:483-792

Johnson KS (1999) Comparative detoxification of plant (Magnolia virginiana) allelochemicals by generalist and specialist Saturniid silkmoths. Journal of Chemical Ecology 25:253-269

Jones CG, W. WD, J. CS, J. SP, S. BM (1989) Reduction in diet breadth results in sequestration of plant chemicals and increases efficacy of chemical defense in a generalist grasshopper. Journal of Chemical Ecology 15:1811-1822

Karban R, English-Loeb G (1997) Tachnid parasitoids affect host plant choice by caterpillars to increase caterpillar survival. Ecology 78:603-611

Kraaijeveld AR, Godfray HCJ (1997) Trade-off between parasitoid resistance and larval competitive ability in Drosophila melanogaster. Nature 389:278-280 
Lampert EC, Bowers MD (2010) Host plant influences on iridoid glycoside sequestration of generalist and specialist caterpillars. Journal of Chemical Ecology 36:1101-1104

Lanza J (1988) Ant preferences for passiflora nectar mimics that contain amino acids. Biotropica 20:341344

Lee TJ, Marples NM, Speed MP (2010) Can dietary conservatism explain the primary evolution of aposematism? Animal Behaviour 79:63-74

Leimar O, Enquist M, Sillén-Tullberg B (1986) Evolutionary stability of aposematic colorarion and prey unprogitability: a theoratical analysis. American Naturalist 128:469-490

Leraut P (ed) (2006) Moths of Europe - Volume 1: Saturnids, Lasiocampids, Hawkmots, Tiger Moths... N.A.P. edn

Lindsey J (2006) The Ecology of Commanster

Lindstedt C (2008) Maintenance of variationin warning signals under opposing selection pressures. Ph.D., University of Jyväskylä, Jyväskylä

Lindstedt C, Lindstrom L, Mappes J (2008) Hairiness and warning colours as components of antipredator defence: additive or interactive benfits? Animal Behaviour 75:1703-1713

Lindstedt C, Lindström L, Mappes J (2009) Thermoregulation can constrain effective warning signal expression. Evolution 63:469-478

Lindstedt C, Reudler Talsma JH, Ihalainen E, Lindstrom L, Mappes J (2010) Diet quality affects warning coloration indirectly: excretion costs in a generalist herbivore. Evolution 64:68-78

Marak HB, Biere A, van Damme JMM (2000) Direct and correlated responses to selection on iridoid glycosides in Plantago lanceolata L. Journal of Evolutionary Biology 13:985-996

Marttila O, Saarinen K, Haahtela T, Pajari M (1996) Suomen kiitäjät ja kehrääjät. Kirjayhtymä, Porvoo

Mason PA, Singer MS (2015) Defensive mixology: combining acquired chemicals towards defence. Functional Ecology 29:441-450

Molleman F, Kaasik A, Whitaker MR, Carey JR (2012) Partitioning variation in duration of ant feeding bouts can offer insights into the palatability of insects: experiments of African fruit-feeding butterflies. The Journal of Research on the Lepidoptera 45:65-75

Nieminen M, Suomi J, van Nouhuys S, Sauri P, Riekkola ML (2003) Effect of iridoid glycoside content on oviposition host plant choice and parasitism in a specialist herbivore. Journal of Chemical Ecology 29:823-844

Nishida R (2002) Sequestration of defensive substances from plants by Lepidoptera. Annual Review of Entomology 47:57-92

Nokelainen O, Valkonen J, Lindstedt C, Mappes J (2012) Changes in predator community structure shifts the efficacy of two warning signals in Arctiid moths. Journal of animal Ecology 83: 598-6050de PJ (2006) Plant chemistry and natural enemy fitness: effects on herbivores and natural enemy interactions. Annual Review of Entomology 51:161-185

Ojala K, Julkunen-Titto R, Lindstrom L, Mappes J (2005) Diet affects the immune defence and life-history traits of an Arctiid moth Parasemia plantaginis. Evolutionary Ecology Research 7:1153-1170

Ojala K, Lindstrom L, Mappes J (2007) Life-history constraints and warning signal expression in an arctiid moth. Functional Ecology 21:1162-1167

Opitz SEW, Jensen SR, Müller C (2010) Sequestration of glucosinolates and iridoid glucosides in sawfly species of the genus Athalia and their role in defense against ants. Journal of Chemical Ecology 36:148-157

Pabis K (2007) New species of Lepidoptera for the Biogradska Gora National Park, Montenegra. Glas. Republ. Zavoda Zast. Prirode. Podgorica 29-30:167-169

Poitout S, Bues R (1974) Élevage de chenilles de vingt-huit espèces de Lépidoptères Noctuidae at de deux espèces d'Arctiidae sur milieu artificiel simple. Particularites de L'élevage selon les espèces. Annales de Zoologie Ecologie Animale 6:431-441 
Price PW, Bouton CE, Gross P, McPheron BA, Thompson JN, Weis AE (1980) Interactions among three trophic levels: influence of plants on interactions between insect herbivores and natural enemies. Annual Review of Ecology and Systematics 11:41-65

Reudler Talsma JH, Tori K, van Nouhuys S (2008) Host plant use by the Heath fritillary butterfly, Melitaea athalia: plant habitat, species and chemistry. Arthropod-Plant Interactions 2: 63-75

Richards LA, Dyer LA, Smilanich AM, Dodson CD (2010) Synergistic effects of amides from two piper species on generalist and specialist herbivores. J Chem Ecol 36:1105-1113

Rimpler H (1991) Sequestration of iridoids by inects. In: Harbone JB, Thomas Barberan FA (eds) Ecological Chemistry and Biochemistry of Plant Terpenoids. Clarendon Press, Oxford, England

Robinson GS, Ackery PR, Kitching IJ, W. BG, Hernández LM (2010) HOSTS - a Database of the World's Lepidopteran Hostplants, vol. 2010. Natural History Museum, London, p a Database of the World's Lepidopteran Hostplants

Rothschild M (1985) British aposematic lepidoptera. In: Heath J, Emmet AM (eds) The moths and butterflies of Great Britain and Ireland. Harely Books, Essex, England, pp 9-62

Rothschild M, Aplin RT, Cockrum PA, Edgar JA, Fairweather P, Lees R (1979) Pyrrolizidine alkaloids in arctiid moths (Lep.) with a discussion on host plant relationships and the role of the secondary plant substances in the Arctiidae. Biological Journal of the Linnean Society 12:305-326

Sagar GR, Harper JL (1964) Biological flora of the British isles. Plantago major L., Plantago media L. and Plantago lanceolata L. Journal of Ecology 52:189-221

Sherratt TN (2002) The coevolution of warning signals. Proceedings of the Royal Society of London Series B-Biological Sciences 269:741-746

Singer MS, Lichter-Marck IH, Farkas TE, Aaron E, Whitney KD, Mooney KA (2014) Herbivore diet breadth mediates the cascading effects of carnivores in food webs. PNAS 111:9521-9526

Singer MS, Mace KC, Bernays EA (2009) Self-medication as adaptive plasticity: increased ingestion of plant toxins by parasitized caterpillars. PLoS ONE 4:e4796

Singer MS, Rodrigues D, Stireman JO, Carrière $Y$ (2004) Roles of food quality and enemy-free space in host use by a generalist insect herbivore. Ecology 85

Smilanich AM, Dyer LA, Chambers JQ, Bowers MD (2009) Immunological cost of chemical defence and the evolution of herbivore diet breath. Ecology Letters 12:612-621

Speed MP, Ruxton GD (2005) Warning displays in spiny animals: one (more) evolutionary route to aposematism. Evolution 59:2499-2508

Speed MP, Ruxton GD, Mappes J, Sherratt T (2013) Why are defensive toxins so variable? An evolutionary perpective. Biological reviews 87:874-884

Stephenson AG (1981) Toxic nectar deters nectar thieves of Catalpa speciosa. American Midland Naturalist 105:381-383

Stermitz FR, Kader MSA, Foderaro TA, Pomeroy M (1994) Iridoid glycosides from some butterflies and their larval food plants. Phytochemistry 37:997-999

Suomi J, Sirén H, Jussila M, Wiedner SK, Riekkola ML (2003) Determination of iridoid glycosides in larvae and adults of butterfly Melitaea cinxia by partial filling micellar electrokinetic capillary chromatography-electrospray ionisation mass spectrometry. Analytical and Bioanalytical Chemistry 376:884-889

Weller SJ, Jacobsen NL, Conner WE (1999) The evolution of chemical defences and mating systems in tiger moths (Lepidoptera: Arctiidae). Biological Journal of the Linnean Society 68:557-578

Willinger G, Dobler S (2001) Selective sequestration of iridoid glycosides from their host plants in Longitarsus flea beetles. Biochemical Systematics and Ecology 29:335-346

Von Nickisch-Rosenegk E, Wink M (1993) Sequestration of pyrrolizdine alkaloids in several arctiid moths (Lepidoptera: Arctiidae). Journal of Chemical Ecology 19:1889-1903 
672 Zhang J, Friman V-P, Laakso J, Mappes J (2012) Interactive effects between diet and genotypes of host 673 and pathogen define the severity of infection. Ecology and Evolution 2: 2347-2356 
675 Table 1a. Average amounts of aucubin, catalpol and both iridoid glycosides (\% dry weight)

676 present in the different diets, measured at two time points. Significant differences $(\mathrm{P}<0.005)$

677 between the diets are indicated with different letter (Tukey Post Hoc test).

\begin{tabular}{llll|lll}
\hline & \multicolumn{3}{l|}{ Start of experiment } & \multicolumn{3}{l}{ After one month } \\
Diet & aucubin & catalpol & total & aucubin & Catalpol & Total \\
& & & & & & \\
\hline 1 & $0.60^{\mathrm{b}}$ & $0.48^{\mathrm{b}}$ & $1.08^{\mathrm{b}}$ & $0.24^{\mathrm{a}}$ & $0.20^{\mathrm{a}}$ & $0.44^{\mathrm{a}}$ \\
2 & $0.19^{\mathrm{a}}$ & $0.20^{\mathrm{a}}$ & $0.39^{\mathrm{a}}$ & $2.09^{\mathrm{ab}}$ & $1.04^{\mathrm{a}}$ & $3.13^{\mathrm{c}}$ \\
3 & $0.68^{\mathrm{b}}$ & $0.34^{\mathrm{ab}}$ & $1.02^{\mathrm{b}}$ & $0.36^{\mathrm{a}}$ & $0.03^{\mathrm{a}}$ & $0.39^{\mathrm{a}}$ \\
4 & $0.89^{\mathrm{c}}$ & $0.86^{\mathrm{c}}$ & $1.75^{\mathrm{c}}$ & $1.25^{\mathrm{ab}}$ & $0.81^{\mathrm{a}}$ & $2.06^{\mathrm{b}}$ \\
5 & $0.27^{\mathrm{a}}$ & $0.37^{\mathrm{b}}$ & $0.63^{\mathrm{a}}$ & $0.63^{\mathrm{ab}}$ & $0.36^{\mathrm{a}}$ & $0.99^{\mathrm{a}}$ \\
6 & $1.78^{\mathrm{d}}$ & $1.45^{\mathrm{d}}$ & $3.24^{\mathrm{d}}$ & $2.85^{\mathrm{b}}$ & $4.45^{\mathrm{b}}$ & $7.29^{\mathrm{d}}$ \\
\hline
\end{tabular}

678 Table 1b. Differences in amounts of IGs (aucubin, catalpol and total IGs) between the different 679 diets, measured at two time points (start of the experiment and one month later).

680

\begin{tabular}{|c|c|c|c|c|c|c|c|}
\hline Source & \multicolumn{2}{|c|}{ Dependent Variable } & $\begin{array}{l}\text { Type } \\
\text { III Sum } \\
\text { of } \\
\text { Squares }\end{array}$ & $\mathrm{df}$ & $\begin{array}{l}\text { Mean } \\
\text { Square }\end{array}$ & $\mathrm{F}$ & $\mathrm{P}$ \\
\hline \multirow[t]{3}{*}{ diet } & Start experiment & Auc & 4.988 & 5 & 0.998 & 186.270 & $<0.001$ \\
\hline & & cat & 3.291 & 5 & 0.658 & 174.244 & $<0.001$ \\
\hline & & iri & 16.072 & 5 & 3.214 & 212.711 & $<0.001$ \\
\hline \multirow[t]{3}{*}{ Error } & & auc & 0.064 & 12 & 0.005 & & \\
\hline & & cat & 0.045 & 12 & 0.004 & & \\
\hline & & iri & 0.181 & 12 & 0.015 & & \\
\hline \multirow[t]{3}{*}{ diet } & After one month & auc & 19.781 & 5 & 3.956 & 4.318 & 0.016 \\
\hline & & cat & 64.835 & 5 & 12.967 & 9.965 & $<0.001$ \\
\hline & & iri & 149.890 & 5 & 29.978 & 174.229 & $<0.001$ \\
\hline \multirow[t]{3}{*}{ Error } & & auc & 11.910 & 13 & 0.916 & & \\
\hline & & cat & 16.915 & 13 & 1.301 & & \\
\hline & & iri & 2.237 & 13 & 0.172 & & \\
\hline
\end{tabular}


683 Figure 1 The mean amounts of iridoid glycosides (IGs) present in the diet at the start of the 684 experiment (A) and one month later (B) and the mean amount of IGs found in the larvae. Black 685 dots represent the larvae from the small signal selection line; white dots represent the larvae from 686 the large signal selection line. Bars indicate standard error.

687

688 Figure 2. Average percentage of catalpol present in the larvae plotted against their selection line 689 (small signal or large signal; categorical variable) (A) or the number of orange body segments 690 (signal size; count varialbe) (B). Bars indicate standard error.

691

692 Figure 3. Average percentage of IGs present in the diets plotted against the average percentage 693 of IGs present in the droppings of the larvae, at the start of the experiment (A) and after one 694 month (B). Bars indicate standard error.

695

696 Figure 4. Average drinking time of the ants (in sec) on the four different solutions: sugar control, 697 aucubin, catalpol and the combined effect of aucubin and catalpol. The different letters indicate 698 significant differences between the treatments $(\mathrm{P}<0.05)$. Bars indicate standard error. 
Figure 1.

700

701

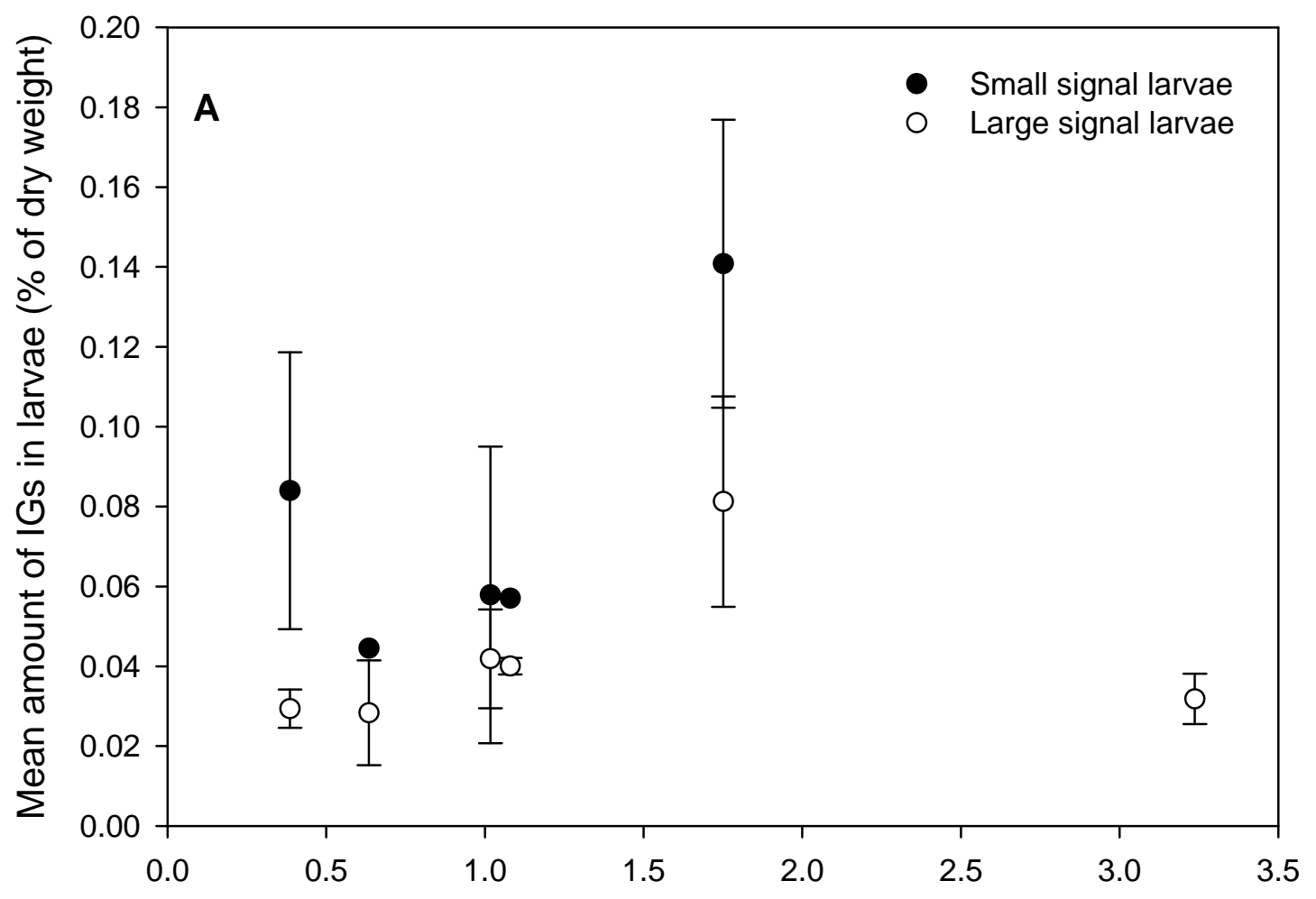

708

Mean amount of IGs in diets (\% of dry weight)

709

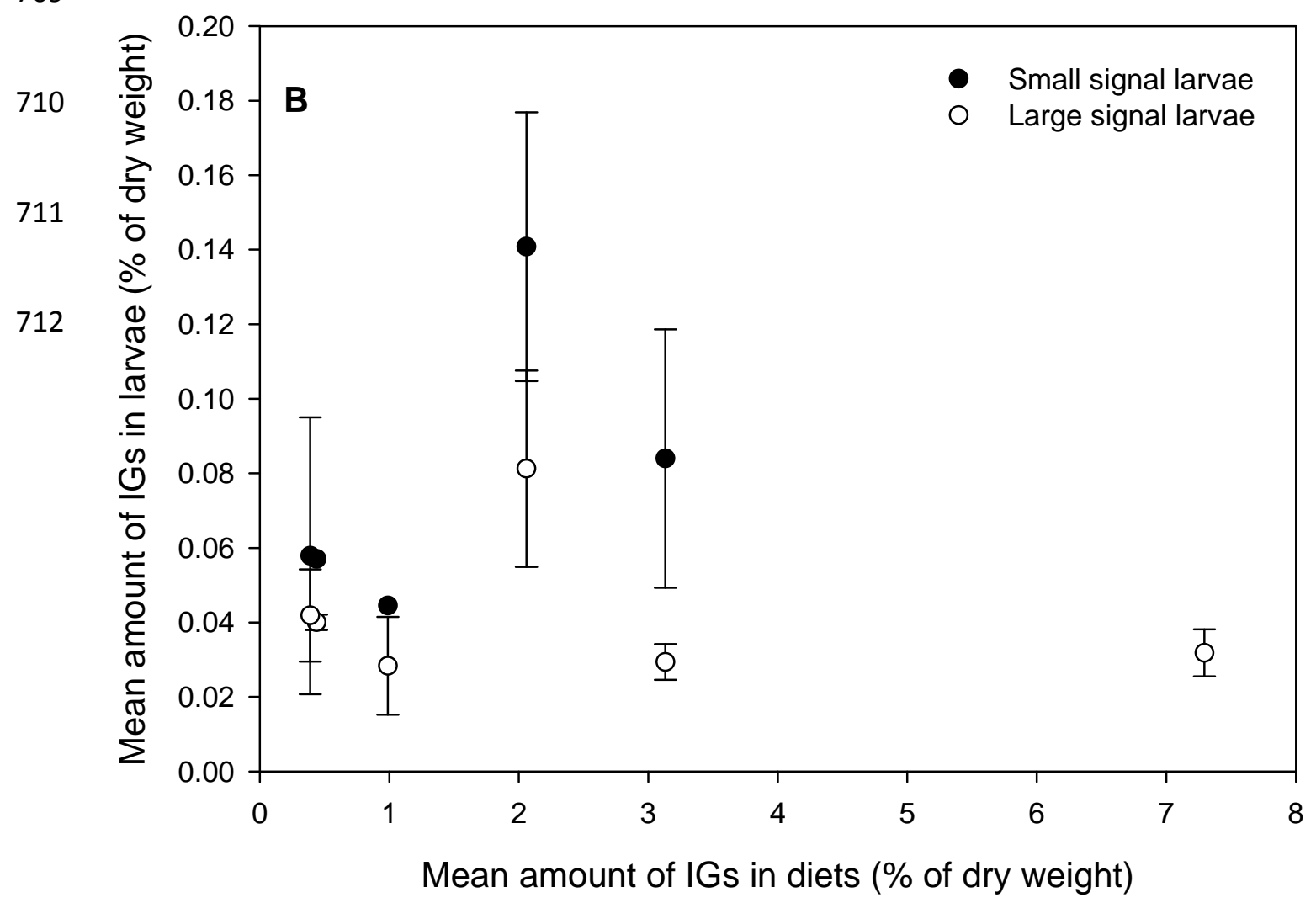


713

714

715

716

717

718

719

720

721

722

723

724

725

726

727

728

729

730

Figure 2

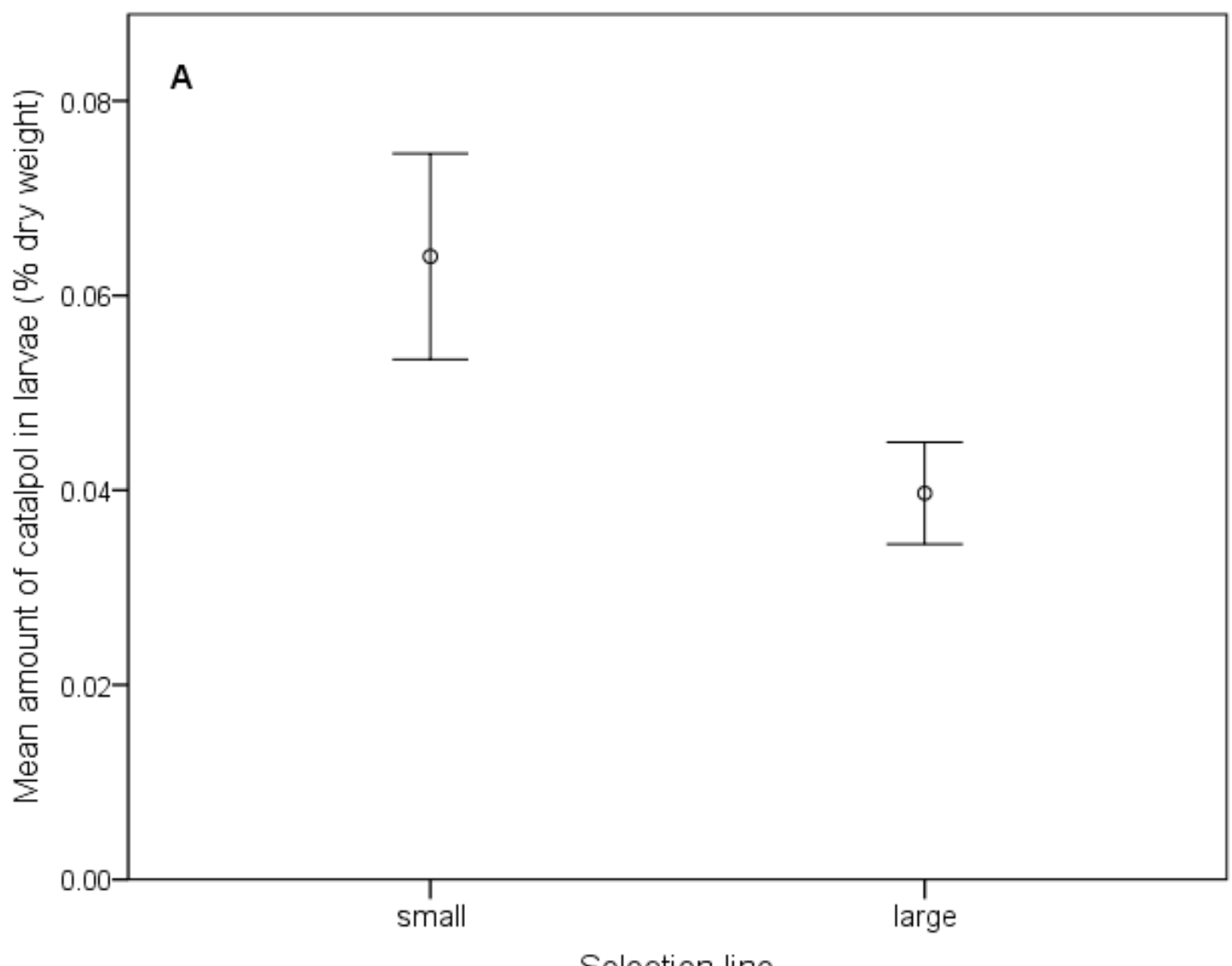

Selection line

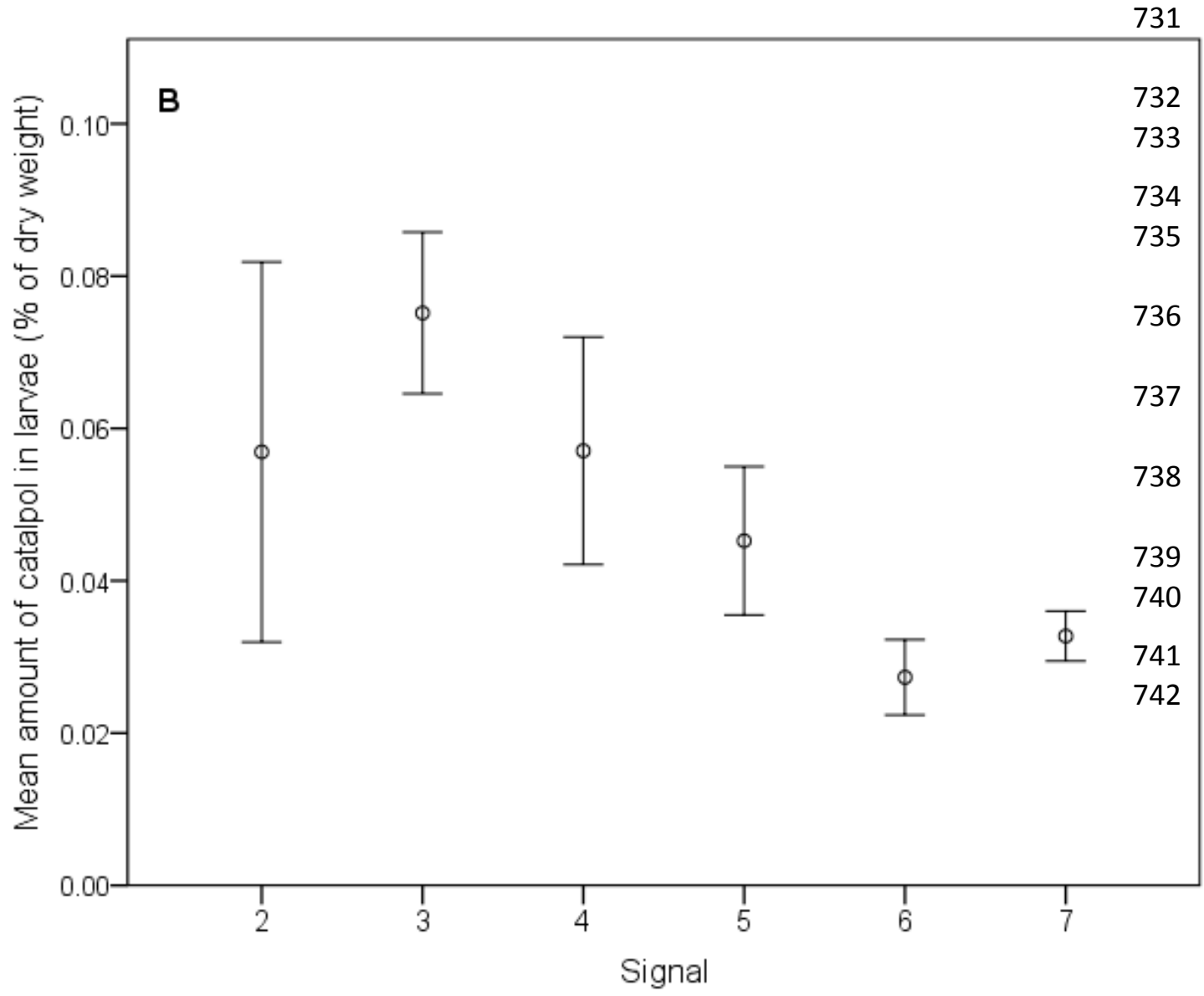


743 Figure 3

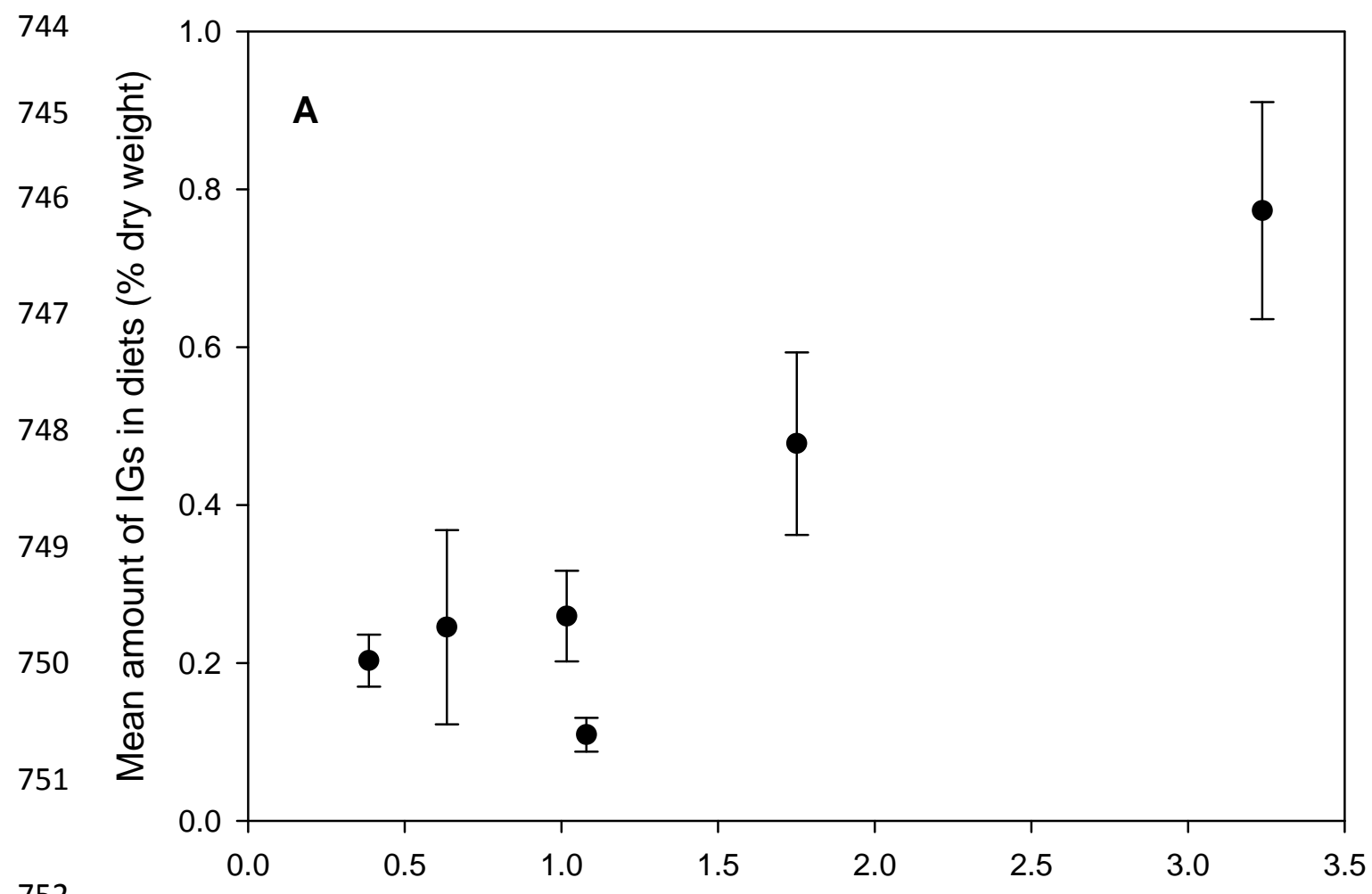

752 Mean amount of IGs in droppings (\% dry weight)

753

754

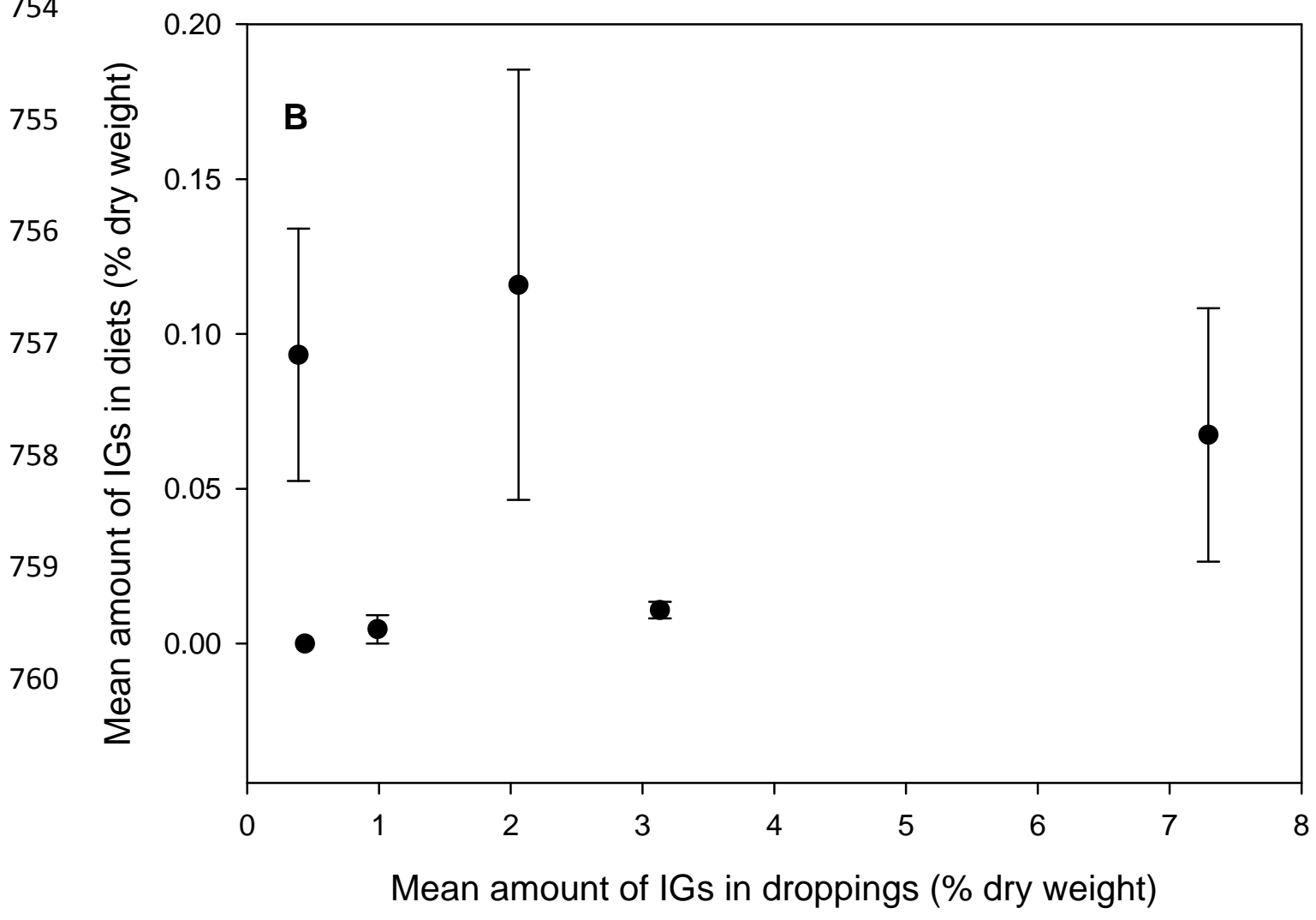


761 Figure 4

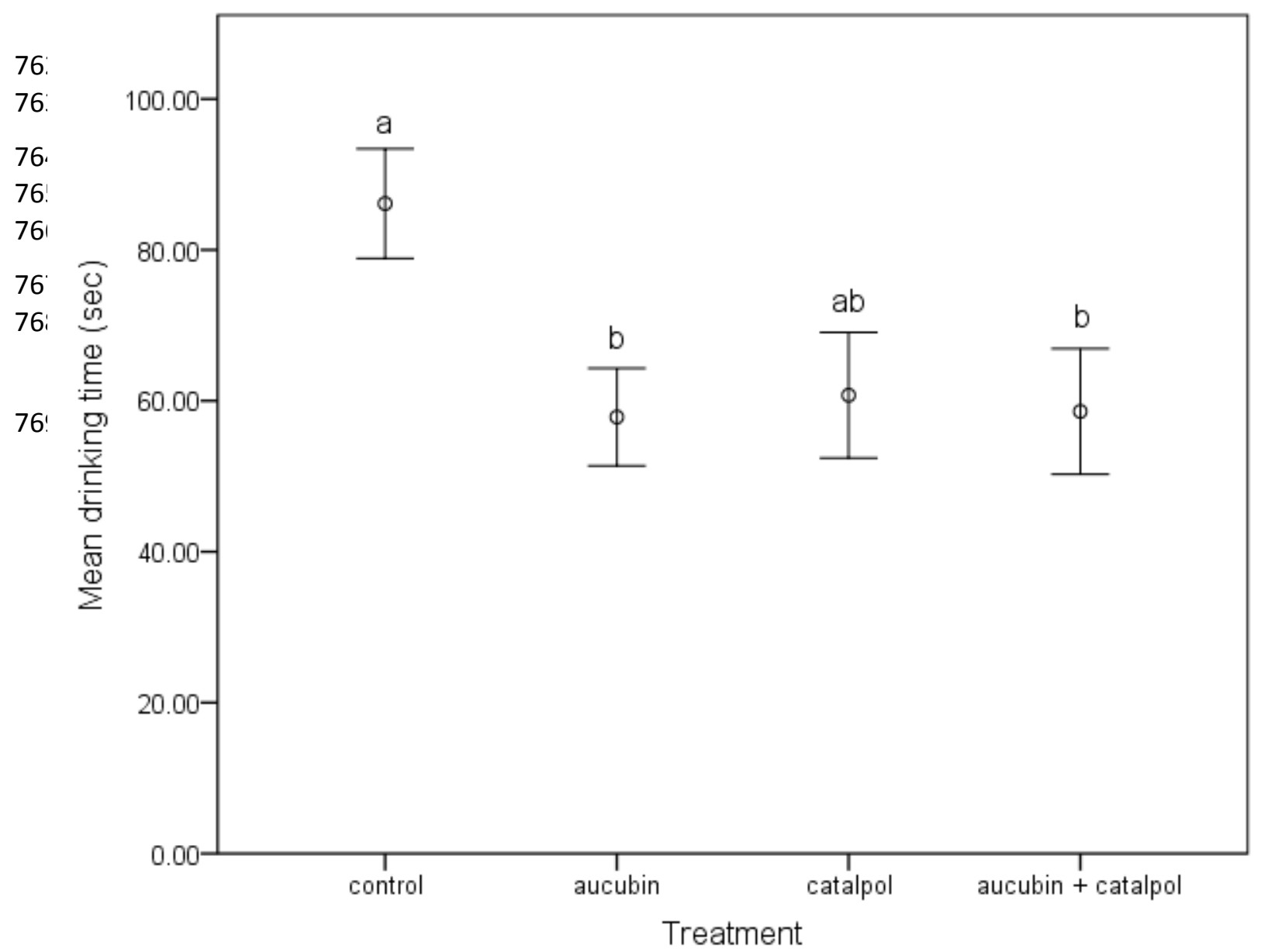

